\title{
The role and diagnostic value of assessing the degree of coronary arteries calcification for predicting the severity of coronary heart disease
}

\author{
A. O. Nykonenko (1),F, A. L. Makarenkov ${ }^{\star A-D}$, H. S. Pidluzhnyi(i), \\ A. M. Materukhin $1 D$ A,C,E
}

Zaporizhzhia State Medical University, Ukraine

A - research concept and design; $\mathrm{B}$ - collection and/or assembly of data; C - data analysis and interpretation; D - writing the article; $\mathrm{E}$ - critical revision of the article; $\mathrm{F}$ - final approval of the article

Coronary heart disease (CHD) is one of the leading mortality causes. According to the latest guidelines, coronary computed tomography angiography (CCTA) is one of the main non-invasive methods for diagnosis of CHD, which allows for quantification of stenosis severity and the characterization of stenotic lesions.

Aim of the study. It is to study the role, diagnostic value and dependence of coronary artery calcification on the degree of stenotic lesion of the coronary arteries and anthropometric parameters in patients with coronary artery disease examined by computed tomography.

Materials and methods. According to the purpose of the study, 46 patients were included: 32 (69.6\%) males and $14(30.4 \%)$ females. The average age of the patients was $59.0 \pm 9.8$ years, height $-172 \pm 9 \mathrm{~cm}$, weight $-85.6 \pm 12.9 \mathrm{~kg}$, body mass index (BMI) $-28.6 \pm 4.13$, body surface area (BSA) $-1.98 \pm 0.17 \mathrm{~m}^{2}$. Demographic and clinical variables were analyzed using descriptive statistics. Independent t-tests were conducted between two groups of patients (Agatston index $\geq 400$ and $<400)$, using $P<0.05$ as a significant value. Pearson correlation coefficient was employed to determine independent coronary calcium predictors using $\mathrm{P}<0.05$ as a significant value.

Results. According to the results of the age analysis, significant differences were found among both groups of patients $(P=0.02)$. Notable differences in the number of affected coronary arteries between Groups 1 and 2 with an Agatston index $\geq 400$ and $<400(P<0.01)$ were found. During the correlation analysis, a significant moderate positive correlation of the SYNTAX score level with Agatston index $(r=0.69, P<0.01)$ was revealed.

Conclusions. The degree of coronary arteries calcification with Agatston score $\geq 400$ is an independent predictor of severe coronary heart disease with multivessel lesion of the coronary arteries. The degree of calcification of coronary arteries with Agatston score $\geq 400$ is more common in males. Height, weight, BMl and BSA do not influence the degree of coronary calcification arteries and Agatston score level.

Роль і діагностична цінність оцінювання ступеня кальцинозу коронарних артерій Аля прогнозування тяжкості ішемічної хвороби серця

\section{А. О. Никоненко, А. А. Макаренков, Г. С. Піммужний, А. М. Матерухін}

Ішемічна хвороба серця (IXC) - одна з провідних причин смертності. За останніми рекомендаціями, комп'ютерна томографічна коронарна ангіографія (КТКА) - один з основних неінвазивних методів діагностики IXC, що дає змогу кількісно визначити ступінь тяжкості стенозу та схарактеризувати стенотичні ураження.

Мета роботи - вивчити роль, діагностичне значення та залежність кальцифікації коронарних артерій від ступеня стенозуючого ураження коронарних артерій та антропометричних показників у пацієнтів з IXC, яких обстежили за допомогою комп'ютерної томограсіії.

Матеріали та методи. У дослідження залучили 46 пацієнтів: 32 (69,6 \%) чоловіків і 14 (30,4 \%) жінок. Середній вік пацієнтів становив 59,0 \pm 9,8 року, зріст $-172 \pm 9$ см, вага $-85,6 \pm 12,9$ кг, індекс маси тіла (IMT) $-28,6 \pm 4,13$,

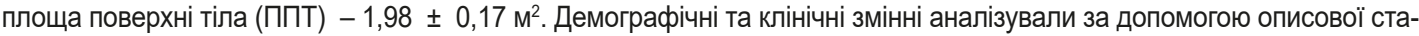
тистики. Незалежні t-тести виконали між двома групами пацієнтів (індекс Агатстона $\geq 400$ та $<400$ ), використовуючи p < 0,05 як значущу величину. Коефріцієнт кореляції Пірсона використовували для визначення незалежних предикторів коронарного кальцію з використанням $p<0,05$ як вірогідного значення.

Результати. За результатами вікового аналізу встановили істотні відмінності між групами пацієнтів $(p=0,02)$. Не виявили вірогідну кореляцію віку з індексом Агатстона ( $r=0,22, p>0,05)$. Визначили вірогідні відмінності за кількістю уражених коронарних артерій між групами 1 і 2 з індексом Агатстона $\geq 400$ та <400 ( $<<0,01)$. Під час кореляційного аналізу виявили суттєву помірну позитивну кореляцію рівня балів SYNTAX з індексом Агатстона $(r=0,69, p<0,01)$.

Висновки. Ступінь кальцифікації коронарних артерій з оцінкою Агатстона $\geq 400 €$ незалежним предиктором тяжкої ішемічної хвороби серця з багатосудинним ураженням коронарного русла. Ступінь кальцифікації коронарних артерій з оцінкою Агатстона $\geq 400$ частіше виявляли в чоловіків. Зріст, вага, ІІМ і ППТ не впливають на ступінь кальцифікації коронарних артерій, рівень балів Агатстона.
Key words: coronary artery, calcium score, coronary computed tomography angiography, SYNTAX score, coronary heart disease.

Pathologia 2021; 18 (1), 39-43

*E-mail: angio.zp@gmail.com

Киючові слова: коронарна артерія, кальцієвий бал, ангіографія коронарної комп'ютерної томографії, шкала SYNTAX, ішемічна хвороба серця.

Патологія. 2021.

T. 18, № 1(51)

C. $39-43$ 
Ключевые слова: коронарная артерия, коронарная компьютерная томографическая ангиография, ишемическая болезнь сердца.

Патология. 2021. T. 18, № 1(51).

C. $39-43$

\section{Роль и диагностическая ценность оценки степени кальциноза коронарных артерий Аля прогнозирования тяжести ишемической болезни сердца}

\section{А. А. Никоненко, А. А. Макаренков, Г. С. Подмужный, А. Н. Матерухин}

Ишемическая болезнь сердца (ИБС) - одна из ведущих причин смертности. Согласно последним рекомендациям, компьютерная томографическая коронарная ангиография (КТКА) является одним из основных неинвазивных методов диагностики ИБС, позволяет количественно определить степень тяжести стеноза и охарактеризовать стенотические поражения.

Цель работы - изучение роли, диагностического значения и зависимости кальцификации коронарных артерий от степени стенозирующего поражения коронарных артерий и антропометрических показателей у пациентов с ИБС, обследованных с помощью компьютерной томографии.

Материалы и методы. В исследование включены 46 пациентов: 32 (69,6 \%) мужчины и 14 (30,4 \%) женщин. Средний возраст пациентов составил 59,0 \pm 9,8 года, рост $-172 \pm 9$ см, вес - 85,6 \pm 12,9 кг, индекс массы тела (ИМТ) - 28,6 \pm 4,13, площадь поверхности тела (ППТ) - 1,98 \pm 0,17 м². Демографические и клинические переменные анализировали с помощью описательной статистики. Независимые t-тесты проводили между двумя группами пациентов (индекс Агатстона $\geq 400$ и <400), используя р < 0,05 как значимую величину. Коэффициент корреляции Пирсона использовали для определения независимых предикторов коронарного кальция с использованием р < 0,05 как достоверного значения.

Результаты. По результатам возрастного анализа установлены существенные различия между группами пациентов ( $p=0,02)$. Однако достоверной корреляции возраста с индексом Агатстона не было ( $r=0,22, p>0,05)$. Обнаружены заметные различия в количестве пораженных коронарных артерий между группами 1 и 2 с индексом Агатстона $\geq 400$ и $<400$ ( $p$ < 0,01). В ходе корреляционного анализа отмечена значимая умеренная положительная корреляция уровня баллов SYNTAX с индексом Агатстона ( $r=0,69, p<0,01)$.

Выводы. Степень кальцификации коронарных артерий с оценкой Агатстона $\geq 400$ - независимый предиктор тяжелой ишемической болезни сердца при многососудистом поражении коронарного русла. Степень кальцификации коронарных артерий с оценкой Агатстона $\geq 400$ чаще определяют у мужчин. Рост, вес, ИМТ и ППТ не влияют на степень кальцификации коронарных артерий и уровень баллов Агатстона.

Coronary heart disease (CHD) is one of the leading mortality causes [1]. According to the latest guidelines, coronary computed tomography angiography (CCTA) is one of the main non-invasive methods for diagnosis of $\mathrm{CHD}$, which allows for quantification of stenosis severity and the characterization of stenotic lesions [2].

A sufficient number of studies has shown that the severity of coronary artery (CA) lesions, assessed on the SYNTAX scale, allows to determine the prognosis associated with the risk of major adverse cardiovascular events (MACE). Further parameters defining the type of surgical intervention and periprocedural risks, taking into account complex lesions of $\mathrm{CA}$, including bifurcation, total chronic occlusion, intraluminal thrombi, calcification and diffuse lesion $[3,4]$.

The coronary artery calcium score (CACS) has predictive value for future coronary events $[5,6]$, but its accuracy for prediction of obstructive coronary artery disease is rather weak. In contrast to CACS, CCTA is a non-invasive method for a more accurate qualitative and quantitative determination of coronary calcium, which has been verified as a lesion with a tomographic optical density of more than 130 Hounsfield units, with the area of $\geq 1 \mathrm{~mm}^{2}[7,8]$. The amount of coronary calcium detected by CCTA correlates with histologically determined atherosclerotic plaques and makes up to $20 \%$ of their total amount [9]. Coronary artery calcium is a highly specific marker of atherosclerosis; it integrates all the risk factors throughout a person's life $[10,11]$, however, the amount of non-calcified fibroatheroma can only be detected by CCTA and is missed by CACS. The correlation between the total coronary calcium score (CACS), measured with Agatston scoring system, and the severity of coronary artery disease are contradictory, weak and unreliable $[12,13]$.

Thus, the feasibility of using data on the degree of calcification of coronary arteries in cardiovascular risk stratification, along with traditional risk factors such as gender, age, smoking, lipid levels, diabetes mellitus and family history, requires further study.

\section{Aim}

It is to study the role, diagnostic value and dependence of coronary artery calcification on the degree of stenotic lesion of the coronary arteries and anthropometric parameters in patients with coronary artery disease examined by computed tomography.

\section{Materials and methods}

The data obtained from patients, who had undergone computed tomography (CT) screening of coronary arteries calcification and CCTA in the period between 2018-2019, were analyzed. The inclusion criteria were signing of informed consent, the presence of coronary heart disease, the presence of calcified atherosclerotic plaques in the coronary arteries walls. The exclusion criteria were the absence of coronary artery atherosclerosis as seen on computed tomography, and the presence of artefacts that compromised the interpretation of CCTA data (motion, pulse, respiratory ones).

According to the purpose of the study, 46 patients were included: 32 males $(69.6 \%)$ and 14 females $(30.4 \%)$. The average age of the patients was $59.0 \pm 9.8$ years, height $-172 \pm 9 \mathrm{~cm}$, weight $-85.6 \pm 12.9 \mathrm{~kg}$, body 
Table 1. Quantitative estimation of calcium and stenotic lesions in the coronary artery

\begin{tabular}{|c|c|c|c|}
\hline Value, units of measure & Group $1(n=23)$ & Group $2(n=23)$ & P-level \\
\hline Males & $20(86.9 \%)$ & $12(52.1 \%)$ & 0.03 \\
\hline Females & $3(13.1 \%)$ & $11(47.9 \%)$ & 0.03 \\
\hline Weight, kg & $87.00 \pm 13.34$ & $84.30 \pm 13.01$ & 0.49 \\
\hline Height, cm & $171.56 \pm 9.51$ & $172.78 \pm 8.85$ & 0.65 \\
\hline Age, years & $62 \pm 7$ & $55 \pm 11$ & 0.02 \\
\hline $\mathrm{BSA}, \mathrm{SI}$ & $1.99 \pm 0,18$ & $1.97 \pm 0,17$ & 0.75 \\
\hline $\mathrm{BMI}, \mathrm{kg} / \mathrm{m}^{2}$ & $29.28 \pm 3.9$ & $27.93 \pm 4.41$ & 0.28 \\
\hline Agatston score $\left(\mathrm{Me}\left[\mathrm{Q}_{25} ; \mathrm{Q}_{75}\right]\right)$ & $1157.0[751.8 ; 1411.0]$ & $137.5[74.0 ; 186.0]$ & $<0.01$ \\
\hline Number of affected coronary arteries $\left(\mathrm{Me}\left[\mathrm{Q}_{25} ; \mathrm{Q}_{71}\right]\right)$ & $3[3 ; 3]$ & $2[1 ; 3]$ & $<0.01$ \\
\hline SYNTAX score $\left(\mathrm{Me}\left[\mathrm{Q}_{25} ; \mathrm{Q}_{75}\right]\right)$ & $26.0[22.0 ; 31.0]$ & $17.5[12.0 ; 27.6]$ & $<0.01$ \\
\hline
\end{tabular}

Abbreviations: parametric data are displayed as mean \pm SD. Counts are shown as $n(\%)$. BMI: body mass index; BSA: body surface area.

mass index (BMI) $-28.6 \pm 4.13$, body surface area (BSA) $-1.98 \pm 0.17 \mathrm{~m}^{2} .232$ patients were excluded from the study.

Grounding on clinical and instrumental data, grade ॥ angina was detected in $15(32.61 \%)$ patients, grade III angina - in $22(47.83 \%)$ patients, grade IV angina -in $6(13.04 \%)$ patients, unstable angina was detected in $3(6.52 \%)$ patients. $17(36.96 \%)$ patients reported to have had previous myocardial infarction. Stage I cardiac insufficiency was detected in 11 (23.91\%) patients, stage II cardiac insufficiency was detected in 35 (76.09\%) patients.

Computer tomography of the heart and coronary arteries was performed with multi-detector 64-pixel computer tomographic scanner Aquilion TSX 101A (Toshiba, Japan). The research was performed in ECG-synchronized mode, with a specific heart rate up to 60 beats per minute. At the first stage, for coronary artery calcium score (CACS) screening, low-dose step-by-step scanning protocol was employed, which was performed in craniocaudal direction from tracheal bifurcation level to diaphragm level, with partition thickness of $3 \mathrm{~mm}$, without intravenous administration of contrast agent (native scanning). At the following stage, a standard MDCT-coronary angiography (CCTA) was performed with retrospective reconstruction of the raw data obtained. Postprocessing was performed with Vitrea workstation (Vital images).

Evaluation of coronary artery calcification from CACS scans was carried out by means of Calcium scoring CT software, which is a part of the software package for the workstation, in semiautomatic mode: the route of each artery was defined manually, whereas there was automatic calculation of coronary calcium score with Agatston scoring system, as well as of the volume of calcified atherosclerotic plaques.

The analysis of stenotic or occlusal lesion of coronary arteries was performed on CCTA datasets with the use of axial partitions, multiple planar and curvilinear reformations, and 3D reconstructions.

The coronary artery lesion index was determined using anatomical SYNTAX score (SYNTAX score) using an online calculator (https://syntaxscore2020.com/).

Demographic and clinical variables were analyzed using descriptive statistics. The Shapiro-Wilk test was used to determine if a data set is well-modeled by a normal distribution. The data set that was normally distributed presented as average and standard deviation $(\mathrm{M} \pm \mathrm{m})$. Independent t-tests were conducted between two groups of patients (Agatston index $\geq 400$ and $<400$ ), using $P<0.05$ as a significant value. In case of deviation from the normal distribution, data was presented as median and interquartile range $\left(\mathrm{Me}\left[\mathrm{Q}_{25} ; \mathrm{Q}_{75}\right]\right)$ and Mann-Whitney $U$-test was used. Spearman's rank correlation coefficient was employed to determine independent coronary calcium predictors using $\mathrm{P}<0.05$ as a significant value. Analyzes were performed with Statistica 13.0 software package (StatSoft Inc., No. JPZ8041382130ARCN10-J).

\section{Results}

According to the purpose of the study and the results of CCTA, the patients were divided into 2 groups: Group 1 included patients with a pronounced degree of coronary arteries calcification and Agatston score level $\geq 400$, and Group 2 comprised patients with moderate and minimal coronary arteries calcification with Agatston score level $<400$. The obtained data are presented in Table 1.

Thus, in both groups there was the same number of patients, while in Group 1 males significantly prevailed $(P<0.05)$, and in Group 2 there were no gender differences.

According to patients' average weight, height, BSA, and BMI, there were no significant differences between the groups; all patients were overweight.

According to the results of the age analysis, significant differences were found among both groups of patients $(P=0.02)$. However, there was no significant correlation of age with the Agatston index $(r=0.22, P>0.05)$.

Notable differences in the number of affected coronary arteries between Groups 1 and 2 with an Agatston index $\geq 400$ and $<400(P<0.01)$ were found.

A significant positive correlation was revealed between the number of stenosed coronary arteries and the Agatston index $(r=0.52, P<0.01)$ in both groups, which is shown in Fig. 1.

Considerable differences were found in Groups 1 and 2 when analyzing SYNTAX score level. So, SYNTAX score in patients of Group 1 was $29.08 \pm 9.44$, which corresponded to the indications for coronary artery bypass grafting and was associated with predictions of cardiac mortality and the risk of major adverse cardiovascular events ranging from $10.9 \%$ to $12.0 \%$ (against up to $23.4 \%$ during percutaneous coronary intervention (PCI)). Whereas the SYNTAX score in patients of Group 2 was $14.39 \pm 5.67$, which corresponded to the indications for $\mathrm{PCl}$ and was associated with predictions of cardiac 


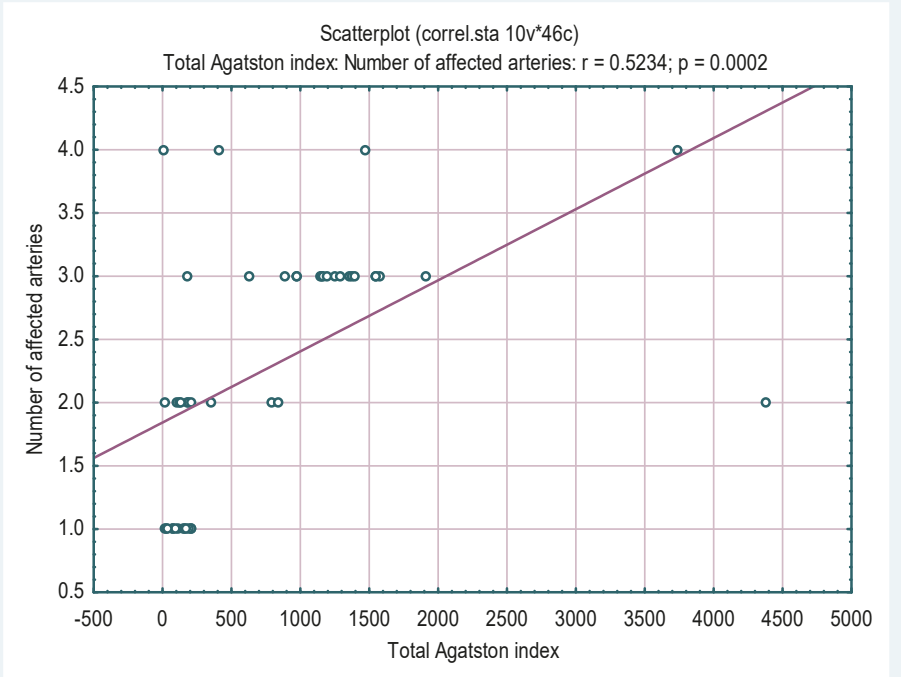

Fig. 1. Correlation of Agatston score level with the number of affected coronary arteries ( $n=46)$.

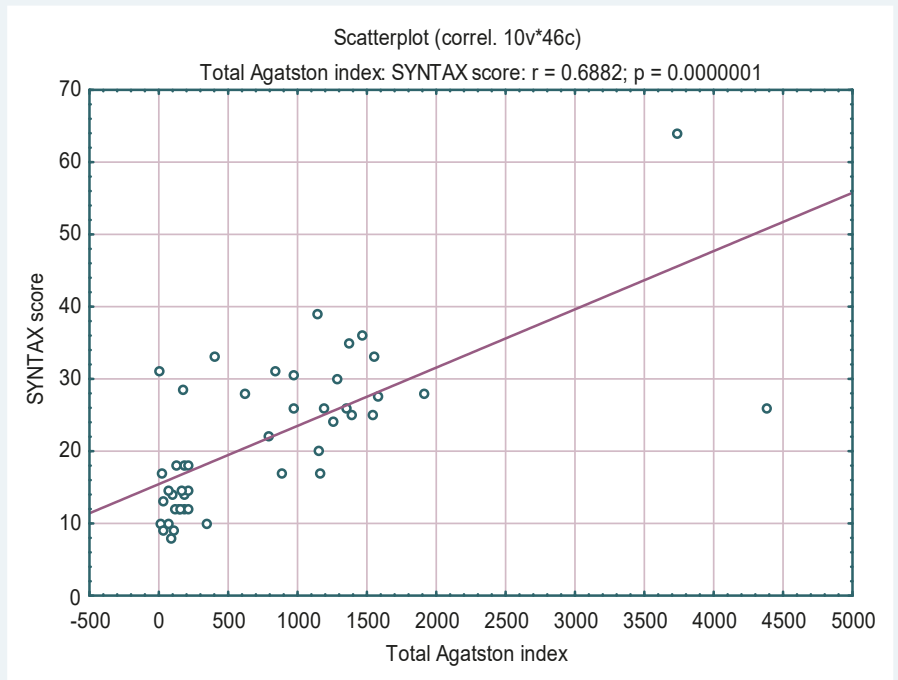

Fig. 2. Correlation of Agatston score level with SYNTAX score level.

mortality and the risk of major adverse cardiovascular events at $13.6 \%$ [4]. During the correlation analysis, a significant moderate positive correlation (Fig. 2) of the SYNTAX score level with Agatston index $(r=0.69$, $\mathrm{P}<0.01$ ) was revealed.

\section{Discussion}

Data on coronary artery calcification provided by CCTA have both diagnostic and prognostic information in addition to the conventional risk factors for coronary artery disease. The presence of calcium confirms coronary atherosclerosis and is associated with an increased risk of coronary events.

According to the data obtained, male patients are more susceptible to pronounced coronary arteries calcification (32 versus 14), with a greater tendency to multivessel lesion. This suggests a possibly more aggressive course of atherosclerosis in males, which is confirmed by the works of other authors [14].
In the course of data analysis, it was found that the degree of coronary calcification is higher in patients of older age groups $(P=0.02)$, which is explained by the progression of atherosclerosis, with a correlation in the number of affected coronary arteries and the complexity of their lesions, expressed in the estimation by SYNTAX score, which leads to higher risks of major adverse cardiovascular events.

The results of our study are comparable with previous reports that age and male gender are independently associated with coronary calcium levels. The correlation between coronary calcification and endothelial dysfunction has also been demonstrated, as well as with impaired myocardial perfusion in patients with angiographic intact coronary arteries [15-17]. Therefore, altered coronary blood flow in the presence of coronary calcification affects the development and formation of atherosclerotic plaques, which are the main determinants of the development of severe forms of coronary artery disease. Besides, coronary calcification is one of the predictors of obstructive coronary artery disease and has predictive value for future coronary events.

Generally, coronary calcium is limited to subintimal space and may occur nearly from the $20^{\text {th }}$ year of a person's life. The calcification of atherosclerotic plaque increases with aging and atherosclerosis progression. Therefore, coronary calcium is a marker of coronary atherosclerosis [18]. Previous studies have examined the association of coronary artery disease with coronary calcium in patients with asymptomatic disease. The prognostic value of calcium screening and its independence from traditional risk factors was shown [18]. Consequently, it is suggested to use coronary calcium levels as a predictor of CHD $[19,20]$. There are also studies that have investigated the importance of coronary calcium for predicting the severity of coronary heart disease $[21,22]$, but our results do not contradict the results of these studies, although different methods have been employed.

\section{Conclusions}

1. The degree of coronary arteries calcification with Agatston score $\geq 400$ is an independent predictor of severe coronary heart disease with multivessel lesion of the coronary arteries.

2. The degree of calcification of coronary arteries with Agatston score $\geq 400$ is more common in males.

3. Height, weight, BMI and BSA do not influence the degree of coronary calcification arteries and Agatston score level.

Prospects for further research. Further research may be focused on elucidating the genotype influence on Agatston score level.

Conflicts of interest: authors have no conflict of interest to declare. Конфмікт інтересів: віАсутній.

Надійшла Ао реАакції / Received: 02.02.2021

Після Аоопрацювання / Revised: 22.02.2021

Прийнято Ао Аруку / Accepted: 05.03.2021 
Information about authors:

Nykonenko A. O., MD, PhD, DSc, Professor, Head of

the Department of Hospital Surgery, Zaporizhzhia State Medical University, Ukraine.

ORCID ID: 0000-0002-5720-2602

Makarenkov A. L., PhD student of the Department of Hospital

Surgery, Zaporizhzhia State Medical University, Ukraine.

ORCID ID: 0000-0003-2132-3776

Pidluzhnyi H. S., Senior Laboratory Assistant of the Department of Hospital Surgery, Zaporizhzhia State Medical University, Ukraine. ORCID ID: 0000-0003-1211-8148

Materukhin A. M., MD, PhD, Associate Professor

of the Department of Hospital Surgery, Zaporizhzhia State

Medical University, Ukraine.

ORCID ID: 0000-0003-2856-6703

\section{Відомості про авторів:}

Никоненко А. О., А-р меА. наук, професор, зав. каф. госпітальної хірургії, Запорізький Аержавний медичний університет, Україна. Макаренков А. ^., заочний аспірант каф. госпітальної хірургії, Запорізький Аержавний медичний університет, Україна. ПіАлужний Г. С., старший лаборант каф. госпітальної хірургії, Запорізький державний медичний університет, Україна. Матерухін А. М., канА. меА. наук, доцент каф. госпітальної хірургії, Запорізький Аержавний медичний університет, Україна.

\section{Сведения об авторах:}

Никоненко А. А., А-р меА. наук, профессор, зав. каф. госпитальной хирургии, Запорожский государственный медицинский университет, Украина. Макаренков А. ^., заочный аспирант каф. госпитальной хирургии, Запорожский государственный медицинский университет, Украина.

ПоАлужный Г. С., старший лаборант каф. госпитальной хирургии, Запорожский государственный медицинский университет, Украина.

Матерухин А. Н., канА. меА. наук, Аоцент каф. госпитальной хирургии, Запорожский государственный меАицинский университет, Украина.

\section{References}

[1] Ministry of Health of Ukraine. (2016, September 23). Unifikovanyi klinichnyi protokol pervynnoi, vtorynnoi (spetsializovanoi) ta tretynnoi (vysokospetsializovanoi) medychnoi dopomohy. Stabilna ishemichna khvoroba sertsia: Nakaz MOZ Ukrainy No. 152 [Unified clinical protocol of the primary, secondary (specialized) and tertiary (highly specialized). Medical care stable ischemic heart disease (No. 152)]. http://mtd.dec. gov.ua/images/dodatki/2016 152 IHS/2016 152 YKPMD IHS.pdf

[2] Knuuti, J., Wijns, W., Saraste, A., Capodanno, D., Barbato, E., Funck-Brentano, C., Prescott, E., Storey, R. F., Deaton, C., Cuisset, T., Agewall, S., Dickstein, K., Edvardsen, T., Escaned, J., Gersh, B. J., Svitil, P., Gilard, M., Hasdai, D., Hatala, R., Mahfoud, F., ... ESC Scientific Document Group (2020). 2019 ESC Guidelines for the diagnosis and management of chronic coronary syndromes. European heart journal, 41(3), 407-477. https://doi.org/10.1093/eurheartj/ehz425

[3] Ndrepepa, G., Tada, T., Fusaro, M., Cassese, S., King, L., Hadamitzky, M., Haase, H. U., Schömig, A., Kastrati, A., \& Pache, J. (2012). Association of coronary atherosclerotic burden with clinical presentation and prognosis in patients with stable and unstable coronary artery disease. Clinical research in cardiology, 101(12), 1003-1011. https:// doi.org/10.1007/s00392-012-0490-9

[4] Farooq, V., Serruys, P. W., Bourantas, C., Vranckx, P., Diletti, R., Garcia Garcia, H. M., Holmes, D. R., Kappetein, A. P., Mack, M., Feldman, T., Morice, M. C., Colombo, A., Morel, M. A., de Vries, T., van Es, G. A., Steyerberg, E. W., Dawkins, K. D., Mohr, F. W., James, S., \& Ståhle, E. (2012). Incidence and multivariable correlates of long-term mortality in patients treated with surgical or percutaneous revascularization in the synergy between percutaneous coronary intervention with taxus and cardiac surgery (SYNTAX) trial. European heart journal, 33(24), 3105-3113. https://doi.org/10.1093/eurhearti/ehs367

[5] Zimmermann, G. S., Rüther, T., Ziegler, F. V., Greif, M., Becker, C., \& Becker, A. (2019). Predictive value of coronary calcifications for future cardiac events in asymptomatic patients: underestimation of risk in asymptomatic smokers. The international journal of cardiovascular imaging, 35(7), 1387-1393. https://doi.org/10.1007/s10554-019-01571-3

[6] Mehta, A., Pandey, A., Ayers, C. R., Khera, A., Sperling, L. S., Szklo, M. S., Gottesman, R. F., Budoff, M. J., Blaha, M. J., Blumenthal, R. S., Nasir, K.,
\& Joshi, P. H. (2020). Predictive Value of Coronary Artery Calcium Score Categories for Coronary Events Versus Strokes: Impact of Sex and Race: MESA and DHS. Circulation. Cardiovascular imaging, 13(8), e010153. https://doi.org/10.1161/CIRCIMAGING.119.010153

[7] Agatston, A. S., Janowitz, W. R., Hildner, F. J., Zusmer, N. R., Viamonte, M., Jr, \& Detrano, R. (1990). Quantification of coronary artery calcium using ultrafast computed tomography. Journal of the American College of Cardiology, 15(4), 827-832. https://doi.org/10.1016/07351097(90)90282-t

[8] de Agustín, J. A., Gómez de Diego, J. J., Marcos-Alberca, P. Mahía, P., Rodrigo, J. L., Luaces, M., Núñez-Gil, I. J., Ferreiros, J., Bustos, A., Cabeza, B., Garcia-Fernández, M. Á., Macaya, C., \& Pérez de Isla, L. (2018). Impact of Calcium Score on Agreement Between Multidetector Computed Tomography and Invasive Coronary Angiography. Revista espanola de cardiologia, 71(2), 105-109. https:// doi.org/10.1016/j.rec.2017.04.012

[9] Tay, S. Y., Chang, P. Y., Lao, W. T., Lin, Y. C., Chung, Y. H., \& Chan, W. P. (2017). The proper use of coronary calcium score and coronary computed tomography angiography for screening asymptomatic patients with cardiovascular risk factors. Scientific reports, 7(1), 17653. https://doi.org/10.1038/s41598-017-17655-w

[10] Rozanski, A., \& Berman, D. S. (2017). Coronary artery calcium scanning in symptomatic patients: Ready for use as a gatekeeper for further testing?. Journal of nuclear cardiology, 24(3), 835-838. https://doi. org/10.1007/s12350-017-0794-2

[11] Greenland, P., Blaha, M. J., Budoff, M. J., Erbel, R., \& Watson, K. E. (2018). Coronary Calcium Score and Cardiovascular Risk. Journal of the American College of Cardiology, 72(4), 434-447. https://doi. org/10.1016/j.jacc.2018.05.027

[12] Sandfort, V., \& Bluemke, D. A. (2017). CT calcium scoring. History, current status and outlook. Diagnostic and interventional imaging, 98(1), 3-10. https://doi.org/10.1016/i.diii.2016.06.007

[13] Malguria, N., Zimmerman, S., \& Fishman, E. K. (2018). Coronary Artery Calcium Scoring: Current Status and Review of Literature. Journal of computer assisted tomography, 42(6), 887-897. https://doi.org/10.1097/ RCT.0000000000000825

[14] Makaryus, A. N., Sison, C., Kohansieh, M., \& Makaryus, J. N. (2015). Implications of Gender Difference in Coronary Calcification as Assessed by CT Coronary Angiography. Clinical Medicine Insights. Cardiology, 8(Suppl 4), 51-55. https://doi.org/10.4137/CMC.S18764

[15] Lee, S. J., Lee, I. K., \& Jeon, J. H. (2020). Vascular Calcification-New Insights Into Its Mechanism. International journal of molecular sciences, 21(8), 2685. https://doi.org/10.3390/ijms21082685

[16] Lee, D. H., Youn, H. J., Jung, H. O., Chang, K., Choi, Y. S., \& Jung, J. I. (2017). Coronary artery calcium score plays an important role for cardiovascular risk stratification in the statin benefit groups of asymptomatic individuals. Lipids in health and disease, 16(1), 172. https:// doi.org/10.1186/s12944-017-0560-0

[17] Klüner, L. V., Oikonomou, E. K., \& Antoniades, C. (2021). Assessing Cardiovascular Risk by Using the Fat Attenuation Index in Coronary CT Angiography. Radiology. Cardiothoracic imaging, 3(1), e200563. https://doi.org/10.1148/ryct.2021200563

[18] Garg, P. K., Jorgensen, N. W., McClelland, R. L., Leigh, J. A., Greenland, P., Blaha, M. J., Yoon, A. J., Wong, N. D., Yeboah, J., \& Budoff, M. J. (2018). Use of coronary artery calcium testing to improve coronary heart disease risk assessment in a lung cancer screening population: The Multi-Ethnic Study of Atherosclerosis (MESA). Journal of cardiovascular computed tomography, 12(6), 493-499. https://doi. org/10.1016/.j.jct.2018.10.001

[19] Venkataraman, P., Stanton, T., Liew, D., Huynh, Q., Nicholls, S. J., Mitchell, G. K., Watts, G. F., Tonkin, A. M., \& Marwick, T. H. (2020). Coronary artery calcium scoring in cardiovascular risk assessment of people with family histories of early onset coronary artery disease. The Medical journal of Australia, 213(4), 170-177. https://doi.org/10.5694/ mia2.50702

[20] Choi, H. Y., Shin, S. J., Yoo, J., Lee, K., Song, D., Kim, Y. D., Nam, H. S., Lee, K. Y., Lee, H. S., Kim, D. J., \& Heo, J. H. (2020). Coronary Calcium Score for the Prediction of Asymptomatic Coronary Artery Disease in Patients With Ischemic Stroke. Frontiers in neurology, 11, 206. https:// doi.org/10.3389/fneur.2020.00206

[21] Stähli, B. E., Bonassin, F., Goetti, R., Küest, S. M., Frank, M., Altwegg, L. A., Gebhard, C., Levis, A., Wischnewsky, M. B., Lüscher, T. F., Alkadhi, H., Kaufmann, P. A., \& Maier, W. (2012). Coronary computed tomography angiography indicates complexity of percutaneous coronary interventions. The Journal of invasive cardiology, 24(5), 196-201.

[22] Schmermund, A., Denktas, A. E., Rumberger, J. A., Christian, T. F., Sheedy, P. F., 2nd, Bailey, K. R., \& Schwartz, R. S. (1999). Independent and incremental value of coronary artery calcium for predicting the extent of angiographic coronary artery disease: comparison with cardiac risk factors and radionuclide perfusion imaging. Journal of the American College of Cardiology, 34(3), 777-786. https://doi. org/10.1016/s0735-1097(99)00265-x 